\title{
A Study of the Interaction Between trans-Dehydrocrotonin, a Bioactive Natural 19-nor-Clerodane, and Serum Albumin
}

\author{
Otávio Augusto Chaves, ${ }^{a}$ Breno A. Soares, ${ }^{b}$ Maria Aparecida M. Maciel, ${ }^{b}$ \\ Carlos Maurício R. Sant'Anna, ${ }^{a}$ José Carlos Netto-Ferreira, ${ }^{a, c}$ Dari Cesarin-Sobrinho ${ }^{a}$ \\ and Aurélio B. B. Ferreira*,a \\ ${ }^{a}$ Departamento de Química, Universidade Federal Rural do Rio de Janeiro, \\ 23970-000 Seropédica-RJ, Brazil \\ ${ }^{b}$ Instituto de Química, Universidade Federal do Rio Grande do Norte, Campus Lagoa Nova, \\ 59072-970 Natal-RN, Brazil \\ 'Instituto Nacional de Metrologia, Qualidade e Tecnologia (INMETRO), Divisão de Metrologia \\ Química, 25250-020 Duque de Caxias-RJ, Brazil
}

\begin{abstract}
The interaction between 19-nor-clerodane trans-dehydrocrotonin (from Croton cajucara Benth.) and bovine serum albumin was studied, applying spectroscopic techniques (fluorescence and circular dichroism), combined with molecular modeling. Fluorescence quenching of albumin by the nor-clerodane ( $\mathrm{k}_{\mathrm{q}}$ ca. $10^{11} \mathrm{~mol} \mathrm{~L}^{-1} \mathrm{~s}^{-1}$ and Stern-Volmer, $\mathrm{K}_{\mathrm{SV}}$, increase with temperature) indicates a combination of static and dynamic quenching mechanism. The binding constant $\left(\mathrm{K}_{\mathrm{b}} \mathrm{ca} .10^{3} \mathrm{~mol} \mathrm{~L}^{-1}\right)$ and circular dichroism data suggest that this association is weak and causes only a moderate change in the $\alpha$-helix content of the protein. Thermodynamic parameters indicate a spontaneous (Gibbs free energy, $\Delta \mathrm{G}^{\circ}$, ca. $-21.28 \mathrm{~kJ} \mathrm{~mol}^{-1}$ at $\left.310 \mathrm{~K}\right)$ and probably entropy-driven $\left(\Delta \mathrm{S}^{\circ}=0.072 \mathrm{~kJ} \mathrm{~mol}^{-1} \mathrm{~K}^{-1}\right)$ association, typical of hydrophobic interactions. The number of binding sites (n ca. 1) indicates one main binding site and molecular modeling suggests subdomain IIIA (Sudlow's site II) as the main binding site to the nor-clerodane, which is able to make hydrophobic interactions with leucine (Leu)-24, phenylalanine (Phe)-36, valine (Val)-40 and tryptophan (Trp)-134 residues.
\end{abstract}

Keywords: Croton cajucara Benth., bovine serum albumin, fluorescence, circular dichroism, molecular modeling

\section{Introduction}

Croton cajucara Benth. (Euphorbiaceae), popularly known as "sacaca", is a widely grown tree of the Amazon region, North of Brazil, used in folk medicine. The stem bark of this plant has been used for the treatment of liver, stomach, and kidney disorders and also to lower the cholesterol levels in the blood. ${ }^{1,2}$ Croton cajucara is a rich source of clerodane type diterpenes, ${ }^{3}$ with trans-dehydrocrotonin, a 19-norclerodane diterpene ( $t$-DCTN), being the major component isolated from its stem bark. This furan clerodane (Figure 1) is one of the most representative bioactive clerodane reported in the literature and became an important target for pre-clinical research. In fact, pharmacological studies employing $t$-DCTN confirmed its anti-inflammatory, analgesic, ${ }^{4}$

*e-mail: aureliobf@uol.com.br

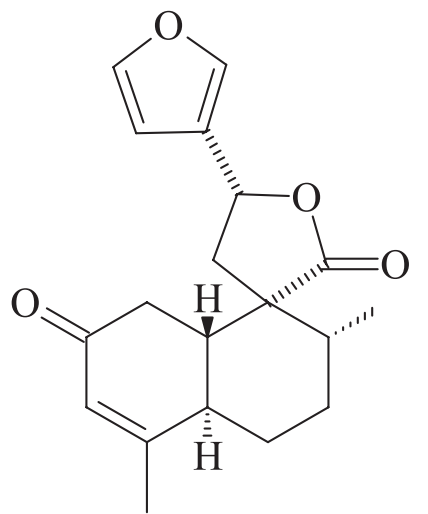

Figure 1. Structure of trans-dehydrocrotonin ( $t$-DCTN).

antitumor, ${ }^{5}$ antiulcer, ${ }^{6,7}$ hypolipidemic and cardioprotective effects. ${ }^{8} t$-DCTN has also been shown to have antimutagenic activity and did not induce clastogenic, anticlastogenic, apoptotic and cytotoxic activities. ${ }^{9}$ 
On the other hand, cases of acute, chronic and fulminant hepatitis have been reported in the Amazon region in patients who used $C$. cajucara in diets to reduce cholesterol $^{10}$ and it has been established that chronic patients treated with an infusion from its bark suffered some toxic effects. This toxicity has been attributed, at least partially, to $t$-DCTN ${ }^{11,12}$ and can be alleviated by the use of encapsulation of the compound in liposomes, ensuring gradual and controlled release in the organism. ${ }^{13}$

Many different molecules are transported in the human blood. ${ }^{14,15}$ Serum albumin is a protein present in the circulatory system, being the main responsible for the distribution and excretion of several endogenous and exogenous ligands, including drugs. ${ }^{16-18}$ As serum albumin accounts for $55 \%$ of the total protein in blood plasma and is easy to purify, it was one of the first proteins to be studied. ${ }^{19}$ Today, a similar protein from cows, i.e., bovine serum albumin (BSA), is widely used in research due to its higher availability and low cost. Besides, its structure shares $76 \%$ identity and $88 \%$ similarity in protein sequence when compared to human serum albumin (HSA). ${ }^{20}$

In the literature it has been observed that $t$-DCTN interacts favorably with phospholipids ${ }^{21}$ and affects the distribution of blood lipids. ${ }^{22}$ So far, no work on the binding study of $t$-DCTN with serum albumin was reported. As serum albumin is the main carrier vehicle for biodistribution of molecules in the human blood, it is very important to understand the interaction between them. In this paper, the interactions between BSA and $t$-DCTN have been studied by using spectroscopic techniques (fluorescence and circular dichroism) combined with molecular modeling. The findings in the present study can contribute to the development of strategies to allow the safe therapeutic use of $t$-DCTN.

\section{Experimental}

\section{Materials}

Plant material was collected in Jacundá, State of Pará (Amazon region, Brazil) and identified by Nelson A. Rosa, botanist of the Museu Paranaense Emílio Goeldi, Belém-PA, Brazil. A voucher specimen (No. 247) has been stored in the Herbarium of the Museu Paraense Emílio Goeldi (Belém, PA, Brazil). The isolation of $t$-DCTN was performed according to the literature. ${ }^{11}$ Commercially available BSA and phosphate-buffered saline (PBS, pH 7.4) were obtained from Sigma-Aldrich (St. Louis, MO, USA). One tablet of PBS dissolved in $200 \mathrm{~mL}$ of deionized water yields $0.01 \mathrm{~mol} \mathrm{~L}^{-1}$ phosphate buffer, $0.0027 \mathrm{~mol} \mathrm{~L}^{-1}$ potassium chloride and $0.137 \mathrm{~mol} \mathrm{~L}^{-1}$ sodium chloride, $\mathrm{pH}$ 7.4, at $298 \mathrm{~K}$. Water used in all experiments was Millipore water (Billerica, MA, USA). Ethanol (spectroscopic grade) was obtained from Vetec (Rio de Janeiro, RJ, Brazil).

\section{Methods and instruments}

Fluorescence spectra were measured on a Jasco J-815 fluorometer (Easton, MD, USA), in a $1 \mathrm{~cm}$ quartz cell and employing a thermostatic cuvette holder Jasco PFD-425S15F. The circular dichroism spectra were measured in a spectropolarimeter Jasco J-815 and employing the same thermostatic cuvette holder. All spectra were recorded with appropriate background corrections.

To a $3 \mathrm{~mL}$ solution containing an appropriate concentration of BSA $\left(1.00 \times 10^{-5} \mathrm{~mol} \mathrm{~L}^{-1}\right)$, successive aliquots from a stock solution of $t$-DCTN $\left(1.00 \times 10^{-3} \mathrm{~mol} \mathrm{~L}^{-1}\right)$ were added, with final concentrations of $0.24,0.47,0.70,0.83,1.15$ and $1.37 \times 10^{-4} \mathrm{~mol} \mathrm{~L}^{-1}$. The addition was done manually by using a micro syringe. The fluorescence spectra were measured in the range $300-450 \mathrm{~nm}$, at 296,303 and $310 \mathrm{~K}$, with excitation wavelength at $280 \mathrm{~nm}$. The circular dichroism spectra were recorded for free BSA $\left(1.00 \times 10^{-6} \mathrm{~mol} \mathrm{~L}^{-1}\right)$ and $t$-DCTN $\left(0.24,0.70\right.$ and $\left.1.15 \times 10^{-4} \mathrm{~mol} \mathrm{~L}^{-1}\right)$, in the range of 200-260 nm, at 296, 303 and $310 \mathrm{~K}$.

\section{Computational methods}

The crystallographic structure of bovine serum albumin was obtained from the Protein Data Bank (PDB) which access code is $4 \mathrm{~F} 5 \mathrm{~S} .{ }^{23}$ This structure has a resolution of $2.47 \AA$. The $t$-DCTN structure was built and energyminimized with the semiempirical method AM1 ${ }^{24}$ available at the Spartan' 14 program. ${ }^{25}$

Molecular docking was performed with Gold 5.2 program. ${ }^{26}$ Hydrogen atoms were added to the protein according to the data inferred by the program on the ionization and tautomeric states. ${ }^{27}$ Docking interaction cavities explored for the docking procedure were delimited by a $10 \AA$ radius from tryptophan (Trp)-134 and Trp-212 residues. The number of genetic operations (crossover, migration, mutation) in each docking run used in the searching procedure was set to 100,000 . The program optimizes hydrogen-bond geometries by rotating hydroxyl and amino groups of the amino acid side chains. The scoring function used was ChemPLP, ${ }^{28}$ which is the default function of the Gold program. ${ }^{26}$ The score of each pose identified is calculated as the negative of the sum of a series of energy terms involved in the protein-ligand interaction process, so that the more positive the score, the better is the interaction. The figures of the docking poses were generated by PyMOL DeLano Scientific LLC program. ${ }^{29}$ 


\section{Results and Discussion}

\section{Fluorescence quenching mechanism}

Fluorescence quenching can be employed to measure the binding affinities since the macromolecules have tryptophan residues as intrinsic fluorophores. ${ }^{30}$ Figure 2 shows BSA fluorescence quenching $\left([\mathrm{BSA}]=1.0 \times 10^{-5} \mathrm{~mol} \mathrm{~L}^{-1}\right)$ of its internal fluorophore (tryptophan residues) by the addition of successive aliquots of $t$-DCTN from a stock solution $\left([t\right.$-DCTN $\left.]=1.0 \times 10^{-3} \mathrm{~mol} \mathrm{~L}^{-1}\right)$ at $296 \mathrm{~K}$, one of the three temperatures employed in this experiment (296, 303 and $310 \mathrm{~K}$ ). This quenching process indicates that the diterpene is located next to a tryptophan residue. ${ }^{31}$ The absence of significant changes in the maximum of the fluorescence emission for $\operatorname{BSA}(\lambda=350 \mathrm{~nm})$ is an evidence that the presence of $t$-DCTN does not exert any influence on the polarity of the microenvironment inside the cavity containing the tryptophan residue..$^{32}$

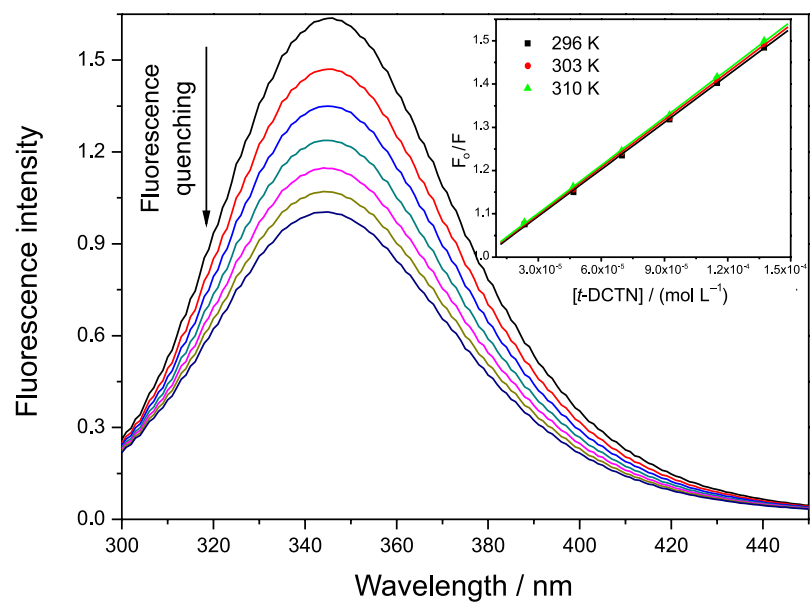

Figure 2. Fluorescence emission spectra of free bovine serum albumin (BSA) and its fluorescence quenching by addition of successive aliquots of 19-nor-clerodane diterpene $(t$-DCTN). BSA prepared in a phosphate-buffered saline (PBS) solution ( $\mathrm{pH} 7.4)$; concentration of $\mathrm{BSA}=1.00 \times 10^{-5} \mathrm{~mol} \mathrm{~L}^{-1}$; concentration of $t$-DCTN $=0.24,0.47,0.70$, $0.83,1.15$, and $1.37 \times 10^{-4} \mathrm{~mol} \mathrm{~L}^{-1} ; \mathrm{T}=296 \mathrm{~K} ; \lambda_{\text {exc }}=280 \mathrm{~nm}$. Inset: Stern-Volmer plot for the fluorescence quenching of BSA by $t$-DCTN at 296, 303 and $310 \mathrm{~K}$.

Stern-Volmer analysis is useful in the estimation of the accessibility of the quencher molecules to the tryptophan residues in proteins as well as in the understanding of the mechanism involved in the quenching process. ${ }^{33}$ The interaction of $t$-DCTN with BSA can be investigated by measuring the change of the intrinsic fluorescence of the later with an increase of $t$-DCTN concentrations, employing the Stern-Volmer (equation 1), as well as the known relationship between bimolecular quenching rate constant of BSA fluorescence $\left(\mathrm{k}_{\mathrm{q}}\right)$ and Stern-Volmer quenching constant $\left(\mathrm{K}_{\mathrm{sv}}\right)$, as shown in equation 2 :
$\frac{\mathrm{F}_{0}}{\mathrm{~F}}=1+\mathrm{k}_{\mathrm{q}} \tau_{0}[\mathrm{Q}]=1+\mathrm{K}_{\mathrm{SV}}[\mathrm{Q}]$

$\mathrm{k}_{\mathrm{q}}=\frac{\mathrm{K}_{\mathrm{SV}}}{\tau_{0}}$

where, $\mathrm{F}_{0}$ and $\mathrm{F}$ are the fluorescence intensities of BSA without and with $t$-DCTN, respectively; [Q] is $t$-DCTN concentration and $\tau_{\mathrm{o}}$ is the lifetime of BSA without $t$-DCTN $\left(10^{-8} \mathrm{~s}\right) .^{34}$

The inset in Figure 2 gives $\mathrm{K}_{\mathrm{SV}}$ values from which $\mathrm{k}_{\mathrm{q}}$ can be calculated. In some cases, the fluorophore, with the same quencher, can be quenched by a combination of static and dynamic quenching mechanism (combined quenching process). ${ }^{35}$ Since the bimolecular quenching rate constants obtained $\left(\mathrm{k}_{\mathrm{q}}\right.$ ca. $10^{11} \mathrm{~mol} \mathrm{~L}^{-1} \mathrm{~s}^{-1}$, Table 1$)$ are two orders of magnitude larger than the diffusion rate constant $\left(\mathrm{k}_{\mathrm{diff}}\right.$ ca. $5 \times 10^{9} \mathrm{~mol} \mathrm{~L}^{-1} \mathrm{~s}^{-1}$ in water, at $\left.298 \mathrm{~K}\right)$, the probable mechanism of fluorescence quenching is static. ${ }^{36,37}$ Static quenching is due to the formation of an association in the ground-state between the fluorophore (albumin) and the quencher $\left(t\right.$-DCTN). ${ }^{33}$ Since the values for the $\mathrm{K}_{\mathrm{SV}}$ increased with increasing temperature, the interaction mechanisms of BSA with $t$-DCTN were not typically of a static type being accompanied by dynamic quenching. ${ }^{38,39}$ This is probably due to the fact that, at high concentrations, a significant amount of the quencher molecules is already in close proximity to the fluorophore.

Binding constants $\left(\mathrm{K}_{\mathrm{b}}\right)$ and number of binding sites $(n)$

If the possibility of more than one binding site between quencher and protein is to be considered, the binding constant for BSA:t-DCTN can be calculated by using the logarithmic relationship expressed by equation 3 (Figure 3 and Table 1): ${ }^{40}$

$\log \frac{\mathrm{F}_{0}-\mathrm{F}}{\mathrm{F}}=\log \mathrm{K}_{\mathrm{b}}+\operatorname{nlog}[\mathrm{Q}]$

where, $\mathrm{F}_{0}$ and $\mathrm{F}$ are the fluorescence intensities in the absence and presence of $t$-DCTN, respectively; $\mathrm{K}_{\mathrm{b}}$ is the binding constant for the multi-binding site case; and $\mathrm{n}$ is the number of binding sites.

As can be seen in Table $1, \mathrm{~K}_{\mathrm{b}}$ values are in the range $10^{3} \mathrm{~mol} \mathrm{~L}^{-1}$, indicating a weak interaction between albumin and $t$-DCTN. ${ }^{41,42}$ Since there are two different tryptophan residues (Trp-134 and Trp-212) located in different pockets in the BSA structure, which are available to interact with the quencher, the number of binding sites was calculated to know if both or just one of these sites is able to interact with 
$t$-DCTN. The $\mathrm{n}$ values at different temperatures ( $\mathrm{n}$ ca. 1.0 at 296, 303 and $310 \mathrm{~K}$ ), indicate the existence of just one main binding site in the BSA structure for $t$-DCTN. ${ }^{41}$ Later on in this paper molecular modeling results will show the possible main cavity in which this interaction is occurring.

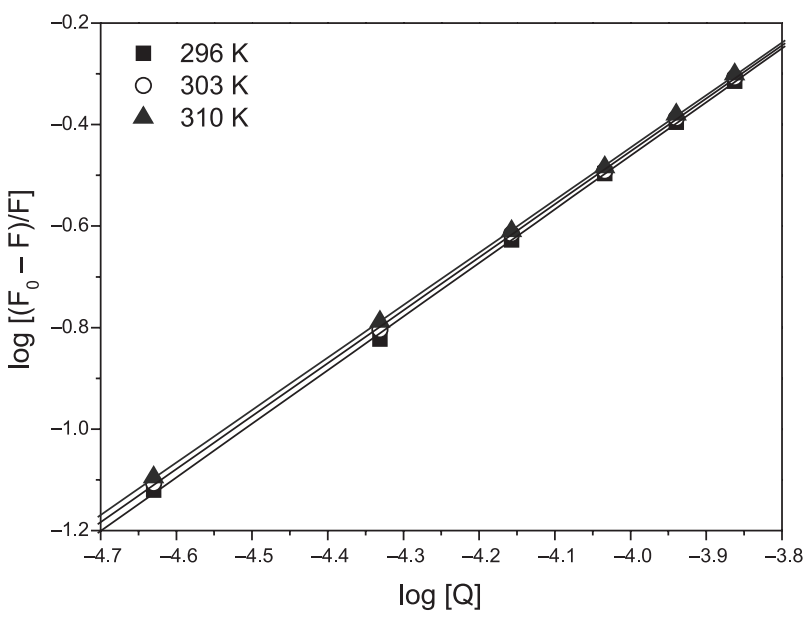

Figure 3. Linear fitting for the plots of $\log \left[\left(\mathrm{F}_{0}-\mathrm{F}\right) / \mathrm{F}\right] v s$. $\log t$-DCTN concentration ([Q]) for free bovine serum albumin (BSA):19-norclerodane diterpene $\left(t\right.$-DCTN) at 296, 303 and $310 \mathrm{~K} . \mathrm{F}_{0}$ and $\mathrm{F}$ are the fluorescence intensities of BSA without and with $t$-DCTN, respectively.

Thermodynamic parameters and the main binding force between $t$-DCTN and BSA

The interaction forces between exogenous agents and proteins (van der Waals and electrostatic forces, including hydrogen bonds and hydrophobic effects) can be related to thermodynamic parameters. In this sense, if enthalpy $\left(\Delta \mathrm{H}^{\circ}\right)>0$ and entropy $\left(\Delta \mathrm{S}^{\circ}\right)>0$, there is an indication that the main force operating is typically through hydrophobic interactions. On the other hand, if $\Delta \mathrm{H}^{\circ}<0$ and $\Delta \mathrm{S}^{\circ}>0$, the main force is due to an electrostatic effect and; finally, if $\Delta \mathrm{H}^{\circ}<0$ and $\Delta \mathrm{S}^{\circ}<0$, van der Waals and hydrogen bond interactions play a major role in the association protein/ exogenous agent. ${ }^{40,43}$

The thermodynamic parameters Gibbs free energy $\left(\Delta \mathrm{G}^{\circ}\right)$, $\Delta \mathrm{H}^{\circ}, \Delta \mathrm{S}^{\circ}$, which control the interaction BSA:t-DCTN, are collected in Table 1 and were obtained using the van't Hoff equation (equation 4; Figure 4) and the Gibbs free energy equation (equation 5 ). ${ }^{29}$

$\ln \mathrm{K}_{\mathrm{SV}}=-\frac{\Delta \mathrm{H}^{\circ}}{\mathrm{RT}}+\frac{\Delta \mathrm{S}^{\circ}}{\mathrm{R}}$

$\Delta \mathrm{G}^{\circ}=\Delta \mathrm{H}^{\circ}-\mathrm{T} \Delta \mathrm{S}^{\circ}$

where, $\Delta \mathrm{H}^{\circ}, \Delta \mathrm{S}^{\circ}, \Delta \mathrm{G}^{\circ}$ are the enthalpy, entropy and Gibbs free energy, respectively; $\mathrm{R}$ is the gas constant $\left(\mathrm{R}=8.314 \times 10^{-3} \mathrm{~kJ} \mathrm{~mol}^{-1} \mathrm{~K}^{-1}\right)$, $\mathrm{T}$ is the temperature (296, 303 and $310 \mathrm{~K}$ ) and $\mathrm{K}_{\mathrm{SV}}$ the Stern-Volmer quenching constant.

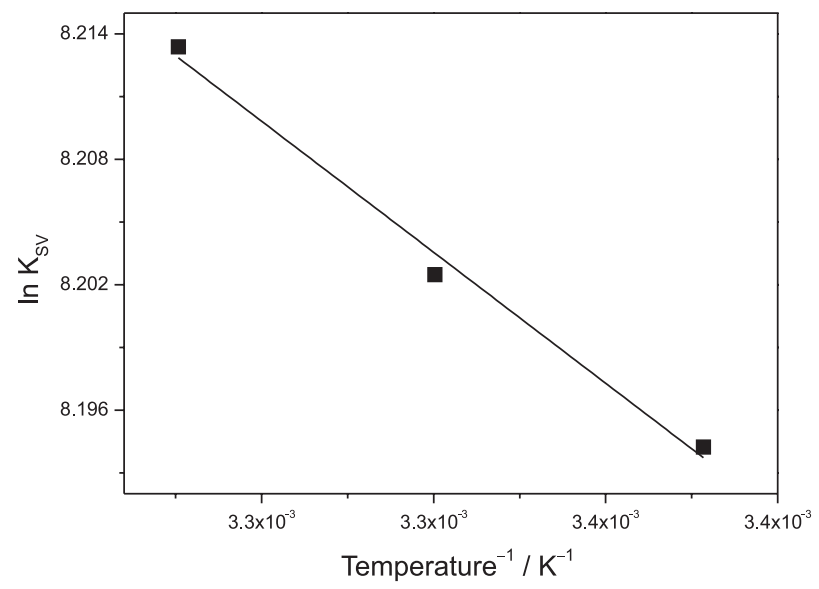

Figure 4. van't Hoff plot of Stern-Volmer quenching constant $\left(\mathrm{K}_{\mathrm{sV}}\right)$ values from Stern-Volmer plots $v s$. inverse of temperature.

Negative values for the Gibbs free energy $\left(\Delta \mathrm{G}^{\circ}\right.$ ca. $-20.78 \mathrm{~kJ} \mathrm{~mol}^{-1}$; Table 1$)$ indicate spontaneous binding, with the unfavorable positive value of enthalpy $\left(\Delta \mathrm{H}^{\circ}=1.04 \mathrm{~kJ} \mathrm{~mol}^{-1}\right)$ being compensate by the positive value of the entropy $\left(\Delta \mathrm{S}^{\circ}=0.072 \mathrm{~kJ} \mathrm{~mol}^{-1} \mathrm{~K}^{-1}\right) .{ }^{43}$ Both enthalpy and entropy are positive, indicating typically hydrophobic interactions between BSA:t-DCTN. ${ }^{40,44}$ These hydrophobic interactions will be explored in the molecular modeling studies, as will be seen in the computational results.

Table 1. Binding parameters Stern-Volmer quenching constant $\left(\mathrm{K}_{\mathrm{SV}}\right)$, bimolecular quenching rate constant of bovine serum albumin (BSA) fluorescence $\left(\mathrm{k}_{\mathrm{q}}\right)$, binding constant for the multi-binding site case $\left(\mathrm{K}_{\mathrm{b}}\right)$ and number of binding sites $(\mathrm{n})$; and thermodynamic parameters enthalpy $\left(\Delta \mathrm{H}^{\circ}\right)$, entropy $\left(\Delta \mathrm{S}^{\circ}\right)$ and Gibbs free energy $\left(\Delta \mathrm{G}^{\circ}\right)$ for BSA:19-nor-clerodane diterpene ( $t$-DCTN) at 296, 303 and $310 \mathrm{~K}$

\begin{tabular}{lccccccc}
\hline Temperature / $\mathrm{K}$ & $\begin{array}{c}\mathrm{K}_{\mathrm{sv}} / \\
\left(\mathrm{mol} \mathrm{L}^{-1}\right)\end{array}$ & $\begin{array}{c}\mathrm{k}_{\mathrm{q}} / \\
\left(\mathrm{mol} \mathrm{L}^{-1} \mathrm{~s}^{-1}\right)\end{array}$ & $\begin{array}{c}\mathrm{K}_{\mathrm{b}} / \\
\left(\mathrm{mol} \mathrm{L}^{-1}\right)\end{array}$ & $\mathrm{n}$ & $\begin{array}{c}\Delta \mathrm{H}^{\circ} / \\
\left(\mathrm{kJ} \mathrm{mol}^{-1}\right)\end{array}$ & $\begin{array}{c}\Delta \mathrm{S}^{\circ} / \\
\left(\mathrm{kJ} \mathrm{mol}^{-1} \mathrm{~K}^{-1}\right)\end{array}$ & $\begin{array}{c}\Delta \mathrm{G}^{\circ} / \\
\left(\mathrm{kJ} \mathrm{mol}^{-1}\right)\end{array}$ \\
\hline 296 & $(3.62 \pm 0.03) \times 10^{3}$ & $3.62 \times 10^{11}$ & $5.81 \times 10^{3}$ & $1.06 \pm 0.01$ & $1.04 \pm 0.01$ & $0.072 \pm 0.004$ & -20.27 \\
303 & $(3.65 \pm 0.03) \times 10^{3}$ & $3.65 \times 10^{11}$ & $5.27 \times 10^{3}$ & $1.04 \pm 0.01$ & $1.04 \pm 0.01$ & $0.072 \pm 0.004$ & -20.78 \\
310 & $(3.69 \pm 0.03) \times 10^{3}$ & $3.69 \times 10^{11}$ & $4.92 \times 10^{3}$ & $1.03 \pm 0.01$ & $1.04 \pm 0.01$ & $0.072 \pm 0.004$ & -21.28 \\
\hline
\end{tabular}


Change in the protein secondary structure induced by $t$-DCTN binding

Circular dichroism (CD) spectroscopy is a sensitive technique used to monitor conformational changes in protein upon interaction with a ligand..$^{45} \mathrm{CD}$ spectra of BSA exhibited two negative bands at 208 and $222 \mathrm{~nm}$, characteristic of $\alpha$-helix structure units of the protein. ${ }^{46} \mathrm{CD}$ spectra (200-260 nm) of BSA were recorded in the absence and presence, at different concentrations, of $t$-DCTN at 296, 303 and $310 \mathrm{~K}$ (Figure 5). Upon increasing the $t$-DCTN concentration in the albumin solution, a small and a moderate decrease in the intensity at 208 and $222 \mathrm{~nm}$, respectively, can be clearly observed. These data indicate a moderate change in the secondary structure of BSA, but the structure of albumin remains predominantly as $\alpha$-helix. ${ }^{47}$ This decrease on the intensity of these two absorptions is probably occurring due to the high kinetic volume of the diterpene.

$\mathrm{CD}$ results can be expressed in terms of significant molar residual ellipticity (MRE) in deg. $\mathrm{cm}^{2} \mathrm{dmol}^{-1}$, calculated according to equation $6: 46$

$\mathrm{MRE}=\frac{\theta}{\left(10 \times \mathrm{n} \times 1 \times \mathrm{C}_{\mathrm{p}}\right)}$

where, $\theta$ is the observed ellipticity (mdeg); $\mathrm{n}$ is the number of amino acid residues (582 to BSA);4 1 is the length of the optical cuvette $(1 \mathrm{~cm})$ and $\mathrm{C}_{\mathrm{p}}$ is the molar concentration of BSA $\left(1.00 \times 10^{-6} \mathrm{~mol} \mathrm{~L}^{-1}\right)$. The loss of helical structure due to ligand binding can also be quantitatively calculated as contents of free and combined BSA from MRE values at 208 and $222 \mathrm{~nm}$, using equations 7 and 8 (Table 2). ${ }^{45}$

$\% \alpha$-helix $=\left[\frac{\left(-\mathrm{MRE}_{208}-4000\right)}{(33000-4000)}\right] \times 100$

$\% \alpha$-helix $=\left[\frac{\left(-\mathrm{MRE}_{222}-2340\right)}{33000}\right] \times 100$

where, $\mathrm{MRE}_{208}$ and $\mathrm{MRE}_{222}$ are the significant molar residual ellipticities $\left(\mathrm{deg} . \mathrm{cm}^{2} \mathrm{dmol}^{-1}\right)$ at 208 and $222 \mathrm{~nm}$, respectively.

In the absence of $t$-DCTN, $\alpha$-helix content in the secondary structure of BSA was calculated to be maximum about 43 and $42 \%$ at 208 and $222 \mathrm{~nm}$, respectively. Practically no change in the $\alpha$-helix content was observed in the presence of diterpene at $208 \mathrm{~nm}(0.41,0.27$ and $1.23 \%$ at 296,303 and $310 \mathrm{~K}$, respectively), but moderate change in the $\alpha$-helix content was observed at $222 \mathrm{~nm}$ (5.68, 5.72 and $7.06 \%$ at 296,303 and $310 \mathrm{~K}$, respectively). Thus, it may be concluded from the CD results that the
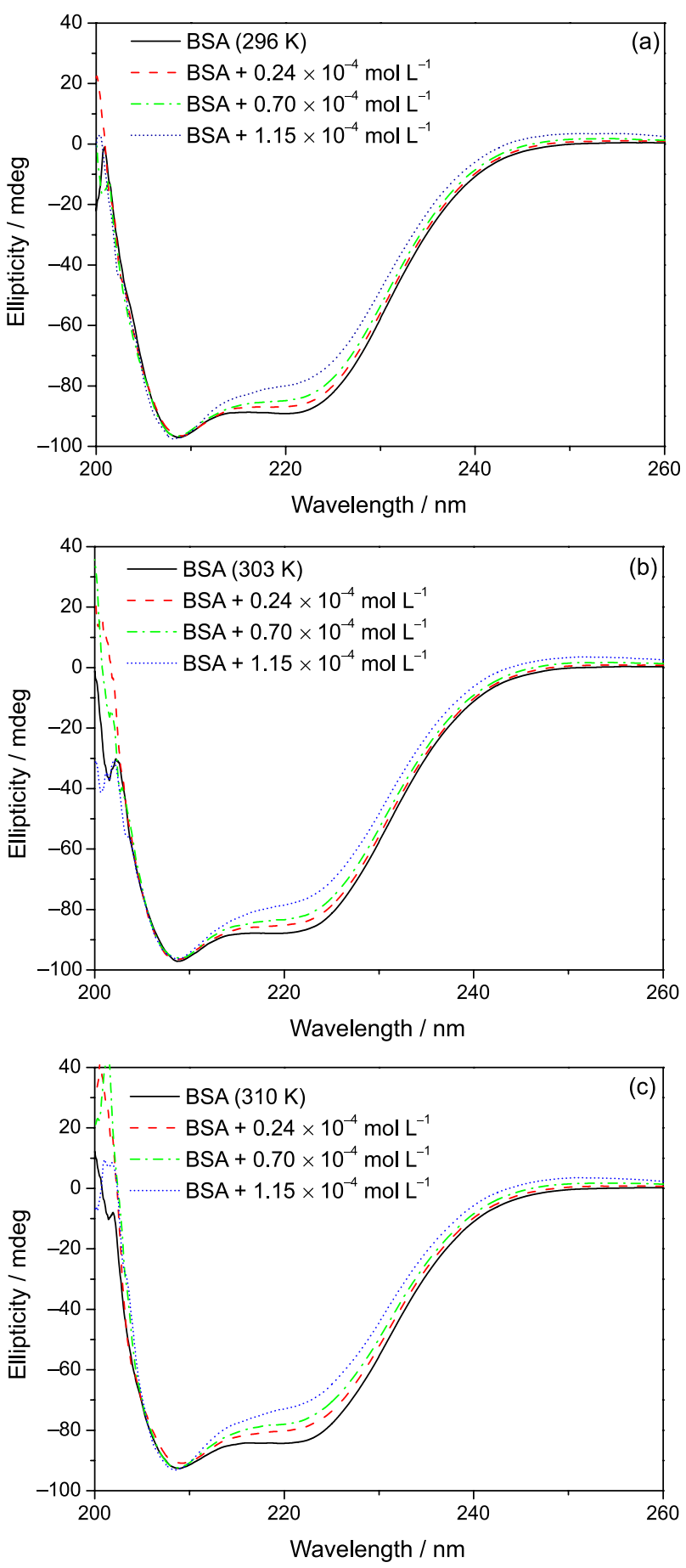

Figure 5. Circular dichroism (CD) spectra of free bovine serum albumin (BSA) and BSA:19-nor-clerodane diterpene ( $t$-DCTN) at different temperatures: $296 \mathrm{~K}$ (a); $303 \mathrm{~K}$ (b); and $310 \mathrm{~K}$ (c). Concentration of $\mathrm{BSA}=1.00 \times 10^{-6} \mathrm{~mol} \mathrm{~L}^{-1}$.

binding should be associated with a moderate change in the secondary structure of the protein, but does not cause any major alteration, such as protein denaturation. ${ }^{49,50}$ Note that $\alpha$-helix $\%$ has an inverse tendency to increase ligand concentration at $222 \mathrm{~nm}$, whereas at $208 \mathrm{~nm}$ the results are random (Table 2), because the sample $t$-DCTN has chiral 
Table 2. Values for $\alpha$-helix at 208 and $222 \mathrm{~nm}$ resulting from the association bovine serum albumin (BSA):19-nor-clerodane diterpene ( $t$-DCNT) at 296, 303 and $310 \mathrm{~K}$

\begin{tabular}{|c|c|c|c|c|c|c|c|}
\hline \multirow{4}{*}{$\begin{array}{l}\text { BSA / } \\
\left(\mathrm{mol} \mathrm{L}^{-1}\right)\end{array}$} & \multirow{4}{*}{$\begin{array}{c}t \text {-DCNT / } \\
\left(\mathrm{mol} \mathrm{L}^{-1}\right)\end{array}$} & \multicolumn{6}{|c|}{ Temperature / K } \\
\hline & & \multicolumn{2}{|c|}{296} & \multicolumn{2}{|c|}{303} & \multicolumn{2}{|c|}{310} \\
\hline & & \multicolumn{6}{|c|}{$\alpha$-Helix / \% } \\
\hline & & 208 & 222 & 208 & 222 & 208 & 222 \\
\hline \multirow{4}{*}{$1.00 \times 10^{-6}$} & - & 43.25 & 42.39 & 42.89 & 41.57 & 40.57 & 39.71 \\
\hline & $0.24 \times 10^{-4}$ & 42.84 & 41.00 & 43.06 & 40.06 & 39.34 & 37.16 \\
\hline & $0.70 \times 10^{-4}$ & 43.24 & 39.71 & 42.62 & 38.86 & 40.54 & 35.78 \\
\hline & $1.15 \times 10^{-4}$ & 43.93 & 36.71 & 42.73 & 35.85 & 41.12 & 32.65 \\
\hline
\end{tabular}

centers that contribute for the cotton effect in the region at $208 \mathrm{~nm}$.

\section{Molecular modeling}

The bovine serum albumin structure consists of three structurally similar domains (I, II and III), each containing two subdomains, A and B. ${ }^{16}$ The Trp-134 residue is located on the surface of the protein, in the hydrophilic region (region IB, Sudlow's site II), whereas the Trp-212 residue is located within a hydrophobic binding pocket (region IIA, Sudlow's site I) ${ }^{51}$ According to the number of binding sites $(\mathrm{n}=1)$ obtained from fluorescence quenching, $t$-DCTN has only one binding site in BSA. ${ }^{42}$ In order to obtain insights into the preferred binding location and to help in a deeper understanding of protein: $t$-DCTN interaction, studies using the molecular modeling technique, such as docking studies, were performed.

Docking score results suggest more favorable interaction of $t$-DCTN in the hydrophilic region, Sudlow's site II (docking score 50.0), than in the hydrophobic binding pocket, Sudlow's site I (docking score 41.5). The site II is a largely apolar cavity that comprised a hydrophobic cleft of about $16 \AA$ deep and $8 \AA$ wide, with a single dominant polar part near the pocket entrance, centered on tyrosine (Tyr)-411 and arginine (Arg)-410 residues. Generally, ligands that bind in the site II have hydroxyl, carbonyl and aromatic carboxylic acids group with a negatively charged acid and a hydrophobic center (e.g., ketoprofen, naproxen, clofibrate and 6-methoxy-2-naphthylacetic acid). On the other hand, ligands that strongly bind to site I are generally dicarboxylic acids and/or bulky heterocyclic molecules with a negative charge and containing azo and/or sulfur groups (e.g., phenylbutazone, azapropazone, tolbutamide, bucolome and sulfisoxazole). ${ }^{52}$ Figure $6 \mathrm{a}$ shows the best docking score pose and the van der Waals surface for $t$-DCTN in Sudlow's site II. $t$-DCTN structure is a bulky heterocyclic that does not have negative charge, dicarboxylic acid, azo and sulfur groups, but has a hydrophobic center that is able to interact in the hydrophobic cleft of the site II, away from the polar pocket centered on Tyr-411 and Arg-410 residues. The experimental thermodynamic parameters indicate hydrophobic interaction as the main binding force between $t$-DCTN and BSA. On the other hand, molecular modeling results suggest that the hydrophobic part of $t$-DCTN is participating through an hydrophobic interaction with four amino acid residues, namely leucine (Leu)-24, phenylalanine (Phe)-36, valine (Val)-40 and Trp-134 . The van der Waals surface of each selected amino acid residue overlaps to the van der Waals surface of $t$-DCTN (Figure 6a), indicating that the interaction between them is highly possible.

Figure $6 \mathrm{~b}$ shows the molecular surface of Sudlow's site II in BSA, suggesting that the polar group of $t$-DCTN, i.e., the furan-lactone moiety, does not have a significant interaction with the polar amino acid residues of albumin, and the major part of the $t$-DCTN structure is more exposed to the solvent and it is not located fully inside the protein.

\section{Conclusions}

The quenching rate constant of BSA fluorescence by $t$-DCTN $\left(\mathrm{k}_{\mathrm{q}}\right.$ ca. $\left.10^{11} \mathrm{~mol} \mathrm{~L}^{-1} \mathrm{~s}^{-1}\right)$ is two orders of magnitude faster than the diffusion rate constant for water and the $\mathrm{K}_{\mathrm{SV}}$ values increase with increasing the temperature, indicating a combination of static and dynamic quenching mechanism. On the other hand, binding constant values $\left(\mathrm{K}_{\mathrm{b}}\right.$ ca. $\left.10^{3} \mathrm{~mol} \mathrm{~L}^{-1}\right)$ obtained from logarithmic plots indicate that the ground-state association of $t$-DCTN with albumin is relatively weak. Molecular modeling suggests that the ligand is more exposed to the solvent than to the inner side of the protein. Thermodynamic parameters indicate that the association BSA:t-DCTN is spontaneous $\left(\Delta \mathrm{G}^{\circ}\right.$ ca. $-21.28 \mathrm{~kJ} \mathrm{~mol}^{-1}$ at $\left.310 \mathrm{~K}\right)$ and 

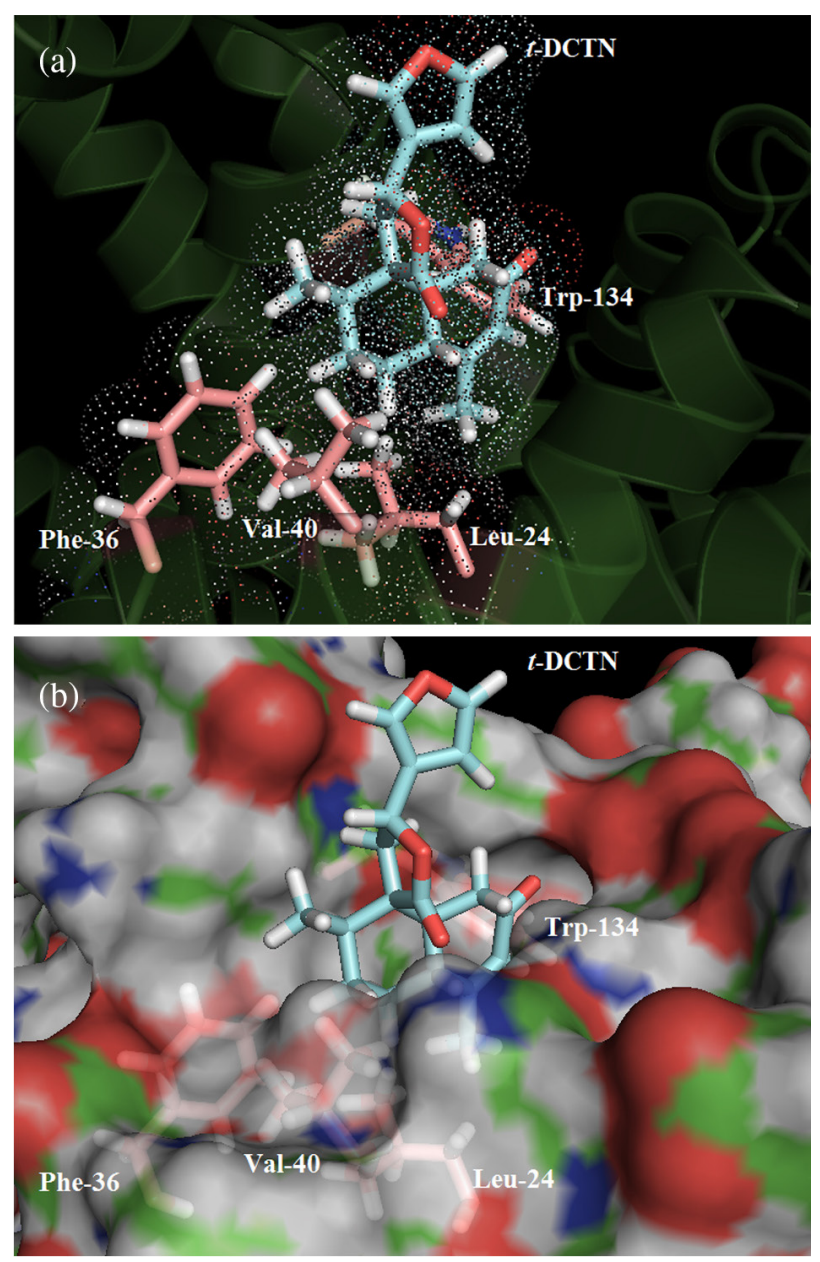

Figure 6. (a) Best score pose and van der Waals surface for 19-norclerodane diterpene $(t$-DCTN) in bovine serum albumin (BSA) in Sudlow's site II, obtained after molecular docking (ChemPLP function); and (b) representation of the molecular surface of BSA to Sudlow's site II. Carbon: cyan ( $t$-DCTN), green (BSA), pink (selected residues); hydrogen: white; oxygen: red; and nitrogen: blue. Figures generated with the PyMOL software. ${ }^{29}$

probably entropically driven $\left(\Delta \mathrm{S}^{\circ}=0.072 \mathrm{~kJ} \mathrm{~mol}^{-1} \mathrm{~K}^{-1}\right.$, or $\mathrm{T} \Delta \mathrm{S}^{\circ}=21.82 \mathrm{~kJ} \mathrm{~mol}^{-1} \mathrm{~K}^{-1}$ at $303 \mathrm{~K}$ ), typically by hydrophobic interactions. $\mathrm{CD}$ data indicate that the binding process can cause a moderate change in the $\alpha$-helix content, whereas the number of binding sites ( $\mathrm{n} \mathrm{ca}$. 1) reveal that there is only one main binding site. Molecular modeling results suggest that the main binding site is in the Sudlow's site II where $t$-DCTN is interacting by hydrophobic interactions with Leu-24, Phe-36, Val-40 and Trp-134 residues.

\section{Acknowledgments}

This research was supported by the Brazilian agencies: Coordenação de Aperfeiçoamento de Pessoal de Nível Superior (CAPES), Conselho Nacional de Desenvolvimento Científico e Tecnológico (CNPq) and Fundação de Amparo à Pesquisa do Estado do Rio de Janeiro (FAPERJ).

\section{References}

1. van den Berg, M. E.; Plantas Medicinais na Amazônia: Contribuição ao seu Conhecimento Sistemático; Conselho Nacional de Desenvolvimento Científico e Tecnológico, Programa Trópico Úmido/Museu Paraense Emílio Goeldi (MPEG): Belém, 1993.

2. di Stasi, L. C.; Hiruma, C. A.; Guimaraes, E. M.; Santos, C. M.; Fitoterapia 1994, 65, 529.

3. Maciel, M. A. M.; Pinto, A. C.; Brabo, S. N.; da Silva, M. N.; Phytochemistry (Elsevier) 1998, 49, 823.

4. Carvalho, J. C. T.; Silva, M. F. C.; Maciel, M. A. M.; Pinto, A. C.; Nunes, D. S.; Lima, R. M.; Bastos, J. K.; Sarti, S. J.; Planta Med. 1996, 62, 402.

5. Grynberg, N. F.; Echevarria, A.; Lima, J. E.; Pamplona, S. S. R.; Pinto, A. C.; Maciel, M. A. M.; Planta Med. 1999, 65, 687.

6. Rodriguez, J. A.; Hiruma-Lima, C. A.; Brito, A. R. M. S.; Hum. Exp. Toxicol. 2004, 23, 455.

7. Hiruma-Lima, C. A.; Spadari-Bratfisch, R. C.; Grassi-Kassisse, D. M.; Brito, A. R. M. S.; Planta Med. 1999, 65, 325.

8. Silva, R. M.; Oliveira, F. A.; Cunha, K. M. A.; Maia, J. L.; Maciel, M. A. M.; Pinto, A. C.; Nascimento, N. R. F.; Santos, F. A.; Rao, V. S. N.; Vasc. Pharmacol. 2005, 43, 11.

9. Santos, F. V.; dos Santos, V. J. S. V.; Farias, M. J.; Mesquita, S. D. F. P.; Maciel, M. A.; Pinto, A. D. C.; Cólus, I. M. D. S.; Biologia (Berlin, Ger.) 2008, 63, 327.

10. Soares, M. C. P.; Rev. Soc. Bras. Med. Trop. 2004, 37, 96.

11. Maciel, M. A. M.; Pinto, A. C.; Arruda, A. C.; Pamplona, S. G. S. R.; Vanderlinde, F. A.; Lapa, A. J.; Echevarria, A.; Grynberg, N. F.; Cólus, I. M. S.; Farias, R. A. F.; Costa, A. M. L.; Rao, V. S. N.; J. Ethnopharmacol. 2000, 70, 41.

12. Rodríguez, J. A.; Hiruma-Lima, C. A.; Souza-Brito, A. R. M.; Hum. Exp. Toxicol. 2004, 23, 455

13. Lapenda, T. L.; Morais, W. A.; Almeida, F. J.; Ferraz, M. S.; Lira, M. C.; Santos, N. P.; Maciel, M. A.; Santos-Magalhães, N. S.; J. Biomed. Nanotechnol. 2013, 3, 499.

14. Sur, S.; Fries, A. C.; Kinzler, K. W.; Zhou, S.; Vogelstein, B.; Proc. Natl. Acad. Sci. U. S. A. 2014, 111, 2283.

15. Fasano, M.; Curry, S.; Terreno, E.; Galliano, M.; Fanali, G.; Narciso, P.; Notari, S.; Ascenzi, P.; IUBMB Life 2005, 57, 787.

16. Lin, V. J.; Koenig, J. L.; Biopolymers 1976, 15, 203.

17. Steel, L. F.; Trotter, M. G.; Nakajima, P. B.; Mattu, T. S.; Gonye, G.; Block, T.; Mol. Cell. Proteomics 2003, 2, 262.

18. Kratz, F.; J. Controlled Release 2008, 132, 171.

19. Yang, F.; Bian, C.; Zhu, L.; Zhao, G.; Huang, Z.; Huang, M.; J. Struct. Biol. 2007, 157, 348.

20. Steinhardt, J.; Krijn, J.; Leidy, J. G.; Biochemistry 1971, 10, 4005.

21. Nascimento Filho, J. M.; de Melo, C. P.; Santos-Magalhães, N. S.; Rosilio, V.; Maciel, M. A. M.; Andrade, C. A. S.; Colloids Surf., A 2010, 358, 42. 
22. Silva, R. M.; Santos, F. A.; Rao, V. S. N.; Maciel, M. A. M.; Pinto, A. C.; J. Pharm. Pharmacol. 2001, 53, 535.

23. Bujacz, A.; Acta Crystallogr., Sect. D: Struct Biol. 2012, D68, 1278.

24. Ferreira, C. A. C.; Ferreira, V. F.; Pinto, A. V.; Lopes, R. S. C.; Pinto, M. C. R.; Silva, A. J. R.; An. Acad. Bras. Cien. 1987, 59,5 .

25. Hehre, W. J.; A Guide to Molecular Mechanics and Quantum Chemical Calculations; Wavefunction, Inc., Irvine, USA, 2003.

26. http://www.ccdc.cam.ac.uk/solutions/csd-discovery/ components/gold/ accessed in February 2016

27. Jones, G.; Willett, P.; Glen, R. C.; Leach, A. R.; Taylor, R.; J. Mol. Biol. 1997, 267, 727.

28. Korb, O.; Stützle, T.; Exner, T. E.; J. Chem. Inf. Model. 2009, $49,84$.

29. DeLano, W. L.; PyMOL User's Guide; DeLano Scientific LLC, USA, 2002.

30. Möller, M.; Denicola, A.; Biochem. Mol. Biol. Educ. 2002, 30, 175.

31. Eftink, M. R.; Ghiron, C. A.; Anal. Biochem. 1981, 114, 199.

32. Tian, J.; Liu, X.; Zhao, Y.; Zhao, S.; Luminescence 2007, 22, 446.

33. Lakowicz, J. R.; Principles of Fluorescence Spectroscopy, $1^{\text {st }}$ ed.; Springer: New York, 2006.

34. Tian, Z.; Zang, F.; Luo, W.; Zhao, Z.; Wang, Y.; Xu, X.; Wang, C.; J. Photochem. Photobiol., B 2015, 142, 103.

35. Lin, H.; Lan, J.; Guan, M.; Sheng, F.; Zhang, H.; Spectrochim. Acta, Part A 2009, 73, 936

36. Eftink, M. R.; Ghiron, C. A.; Anal. Bioanal. Chem. 1981, 114, 199.

37. Brune, D.; Kim, S.; Biophysics 1993, 90, 3835.
38. Tian, Z.-Y.; Song, L.-N.; Zhao, Y.; Zang, F.-L.; Zhao, Z.-H.; Chen, N.-H.; Xu, X.-J.; Wang, C.-J.; Molecules 2015, 20, 16491.

39. Zhang, J.; Chen, L.; Zeng, B.; Kang, Q.; Dai, L.; Spectrochim. Acta, Part A 2013, 105, 74.

40. Bi, S.; Yan, L.; Pang, B.; Wang, Y.; J. Lumin. 2012, 132, 132.

41. Bakkialakshmi, S.; Chandrakala, D.; Spectrochim. Acta, Part A 2012, 88,2 .

42. Belatik, A.; Hotchandani, S.; Bariyanga, J.; Tajmir-Riahi, H. A.; Eur. J. Med. Chem. 2012, 48, 114.

43. Timaseff, S. N. In Proteins of Biological Fluids; Pecters, H., ed.; Pergamon Press: Oxford, 1972, p. 511.

44. Ross, P. D.; Subramanian, S.; Biochemistry 1981, 20, 3096.

45. Varlan, A.; Hillebrand, M.; Molecules 2010, 15, 3905.

46. He, Y.; Wang, Y.; Tang, L.; Liu, H.; Chen, W.; Zheng, Z.; Zou, G.; J. Fluoresc. 2008, 18, 433.

47. Khan, S. N.; Islam, B.; Yennamalli, R.; Sultan, A.; Subbarao, N.; Khan, A. U.; Eur. J. Pharm. Sci. 2008, 35, 371.

48. Wang, Y. P.; Wei, Y.; Dong, C.; J. Photochem. Photobiol., A 2006, 177, 6 .

49. Zsila, F.; Bikadi, Z.; Simonyi, M.; Biochem. Pharmacol. (Amsterdam, Neth.) 2003, 65, 447.

50. Kandagal, P. B.; Ashoka, S.; Seetharamappa, J.; Shaikh, S. M. T.; Jadegoud, Y.; Ijare, O. B.; J. Pharm. Biomed. Anal. 2006, 41, 393.

51. Bhattacharya, B.; Nakka, S.; Guruprasad, L.; Samanta, A.; J. Phys. Chem. B 2009, 113, 2143.

52. Yamasaki, K.; Chuang, V. T. G.; Maruyama, T.; Otagiri, M.; Biochim. Biophys. Acta 2013, 1830, 5435.

Submitted: January 6, 2016

Published online: March 4, 2016 